\title{
Cascading impacts of climate change on southwestern US cropland agriculture
}

\author{
Caitriana Steele ${ }^{1,2} \cdot$ Julian Reyes $^{2} \cdot$ Emile Elias $^{2}$ • \\ Sierra Aney ${ }^{3}$ - Albert Rango ${ }^{2}$
}

Received: 28 September 2017 / Accepted: 13 May 2018 /Published online: 31 May 2018

(C) The Author(s) 2018

\begin{abstract}
The interior southwest United States is one of the hottest, driest regions on the planet, yet irrigated cropland agriculture is successfully practiced where there is access to surface water and/or groundwater. Through climate change, the southwest is projected to become even hotter and drier, increasing the challenges faced by farmers across the region. We can assess the vulnerability of cropland agriculture, to assist in developing potential solutions to these challenges of warming temperatures and water scarcity. However, these types of biophysical vulnerability assessment usually generate technological or policy-level solutions that do not necessarily account for farmers' ability to respond to climate change impacts. Further, there are non-climatic factors that also threaten the future of agriculture in the region, such as population increase, loss of agricultural land, and increasing competition for depleting water resources. In this paper, we assert that to fully address how southwestern farmers may
\end{abstract}

This article is part of a Special Issue on "Vulnerability of Regional Forest and Agricultural Ecosystems to a Changing Climate (USDA Southwest Climate Hub)" edited by David Gutzler and Connie Maxwell.

Electronic supplementary material The online version of this article (https://doi.org/10.1007/s10584-0182220-4) contains supplementary material, which is available to authorized users.

Caitriana Steele

caiti@nmsu.edu

Emile Elias

emile.elias@ars.usda.gov

Sierra Aney

sierra25@nmsu.edu

Albert Rango

albert.rango@ars.usda.gov

1 Department of Plant and Environmental Sciences, New Mexico State University, Las Cruces, NM, USA

2 USDA-Agricultural Research Service, Jornada Experimental Range, Las Cruces, NM, USA

3 Department of Geography, New Mexico State University, Las Cruces, NM, USA 
respond to climate change impacts, we must consider both biophysical outcome and contextual vulnerabilities. Future research on individual localities and/or specific commodities and including cross-disciplinary analysis of socio-economic, institutional, cultural, and political factors alongside biophysical factors will help to develop more substantive understanding of system vulnerabilities and feasible adaptive solutions.

\section{Introduction}

Climate change threatens successful agriculture in the Southwest. While all farming operations are likely to experience rising temperatures and changes in precipitation over the coming decades, the degree of negative (or positive) impact from a changing climate will vary according to location, crops grown, access to water, and other interacting biophysical factors (e.g., pests, pathogens, soil health). Further, climate impacts are superimposed over a "backdrop of conventional drivers" including economic, institutional, cultural, and political factors (Marshall et al. 2014).

Vulnerability assessments have been widely used for identifying solutions to the climatemediated challenges facing agricultural activities. Many of these draw upon the Intergovernmental Panel on Climate Change (IPCC) conceptual model, where vulnerability is shown as a function of exposure, sensitivity, and adaptive capacity (McCarthy et al. 2001; Fig. 1). Here, exposure refers to the external stress or pressure imposed on a system. Sensitivity is the system's inherent ability to tolerate (or benefit from) external stimuli. Adaptive capacity describes "the ability of a system to adjust to climate change (including climate variability and extremes), to moderate potential damages, to take advantage of opportunities, or to cope with the consequences" (McCarthy et al. 2001). Some researchers liken adaptive capacity to other widely used concepts including management capacity and resilience (Smit and Wandel 2006).

These linear types of assessment typify outcome vulnerability (Kelly and Adger 2000; O'Brien et al. 2007) in that they are used to produce quantitative or qualitative estimates of vulnerability and technical, infrastructural, or policy-level adaptive responses. In cropland studies, researchers usually combine climate data with physical, empirical, or conceptual biophysical response models to provide the material for impact assessment, which in turn guides the identification of adaptive solutions (e.g., Iglesias and Minguez 1997; Wilhelmi and Wilhite 2002). Building an understanding of biophysical outcome vulnerabilities is essential

Fig. 1 The IPCC definition of vulnerability (McCarthy et al. 2001)

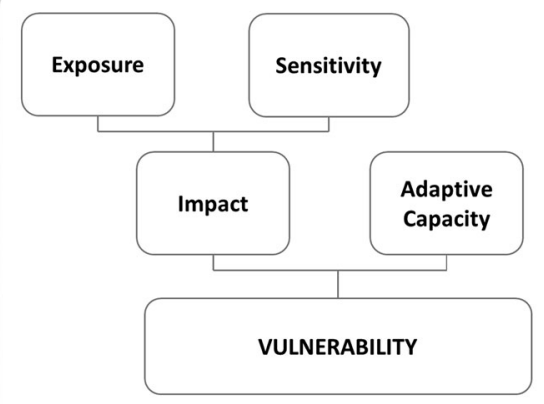


for adaptation planning, because it supplies the vision of future climate change challenges and solutions. However, climate change will have differential impacts influenced by interacting biophysical, socio-economic, and institutional factors. Resource-dependent communities will be exposed first hand to the effects of climate change, leading to primary effects on crop productivity and income, but there will also be secondary effects cascading through the system and any number of interactions between connected systems at multiple scales (Adger 2003).

How we frame climate change vulnerability drives the questions we ask, the knowledge we generate through our research, and determines whether solutions are to be found in technical adaptations, policy responses, or other means of enhancing adaptive capacity (O'Brien et al. 2007). Viewing vulnerability through a linear framework generates potential adaptive solutions, but does not necessarily consider exogenous barriers to adaptation that are connected to the vulnerable system. Further, the stochasticity and non-linearity of interactions within the coupled system can result in unexpected situations (Turner et al. 2003). Alternative approaches focus on contextual vulnerability, which considers the existing socio-economic, political, and institutional context in which climate change impacts occur (Kelly and Adger 2000; O'Brien et al. 2007). Specifically, recognizing how contextual conditions control a system's capacity to cope, adapt, or transform is critical to reducing future vulnerability and avoiding maladaptive solutions.

Our objective in this paper is to demonstrate how in different locations, different cropping systems exposed to similar changes in future climate may experience increased or reduced vulnerability from various contextual factors. In support of this, we visualized a framework for mapping the wide range of important considerations, conceptualizing interactions between institutional, political, and socio-economic drivers of vulnerability in southwestern cropland systems (Fig. 2). External stress imposed on a system may come from many quarters besides climate change, including population growth, urban expansion, markets, government policies, and other formal and informal institutions (Turner et al. 2003; O'Brien et al. 2007). And there are interactions between these stressors which may ameliorate or exacerbate damage triggered by climate change impacts. Further, some stressors may be important in one location, or to a specific commodity group, while having little relevance in other locations or to other commodity groups. Added to this complexity, certain factors may have either positive or negative associations with exposure, sensitivity, and/or adaptive capacity.

Figure 2 is divided into two parts. The central shaded area embodies the core biophysical components of the framework (including land and soil, water, and cropping systems), which are exposed to impacts from climate change, population growth, and urban expansion. In turn, the functioning of the biophysical components feeds through to crop yields, producers' income, and livelihood security.

Population growth and urban development are included in the core part of the framework, because in some southwestern locations, these variables are as important as climate change impacts (see Section 2.2). As the exurban fringe continues to spread, more agricultural land is converted for residential development. Population growth also has the potential to cause future conflicts between urban and agricultural users of water, as the region experiences greater demands for water from cities (Liverman and Merideth 2002; MacDonald 2010). Conversely, there may be positive impacts associated with urbanization, including potential transition to higher value crops with proximity to local markets, and greater opportunities for off-farm employment and on-farm agritourism activities.

Livestock and diversified activities are also represented in the core part of the framework. Livestock agriculture accounts for between $40 \%$ (Arizona) to $~ 70 \%$ (Utah, New Mexico) of 


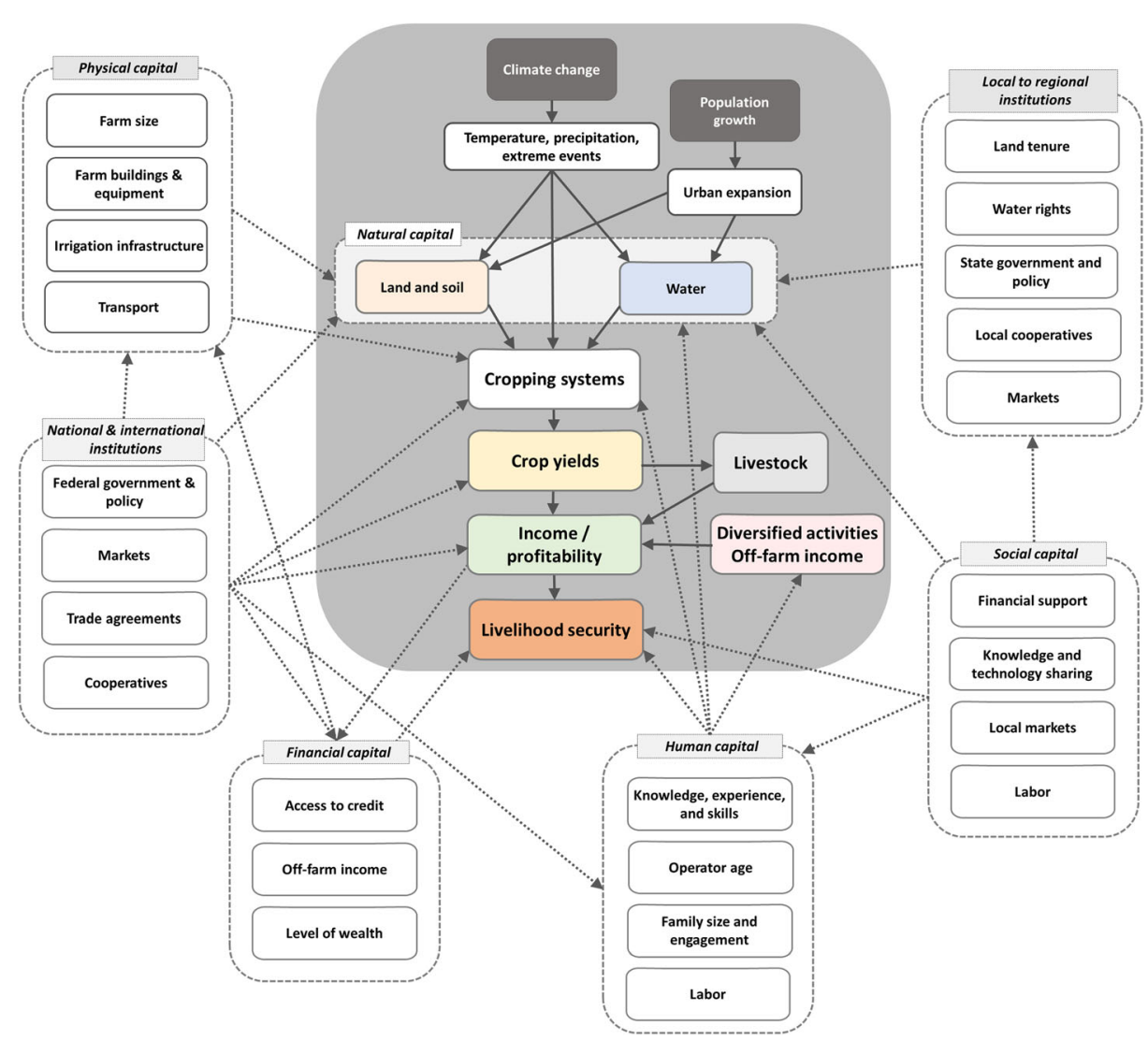

Fig. 2 Conceptual framework illustrating interacting biophysical and socio-economic factors affecting vulnerability in southwestern cropland systems

total agricultural sales in the three states (USDA NASS 2014), and many southwestern livestock producers raise crops for their own livestock. Additionally, some producers rely on alternative activities such as agritourism, to support farm income. Agritourism generated $\sim \$ 24$ million in the three-state region in 2012 (USDA NASS 2014).

Contextual factors are summarized in boxes surrounding the core cropland system in Fig. 2 and are connected to other system components with dashed lines. We listed only a few examples in each box; there are potentially many more, but space prevents their inclusion here. We classified contextual factors as either capital assets or formal institutions. We borrowed the capital assets terminology from the sustainable livelihoods literature, where the concept has been applied in analysis of livelihood strategies primarily in developing nations (e.g., Bebbington 1999). In all cases, we assumed that better access to all types of capital has the potential to either reduce sensitivity or increase adaptive capacity. Here, examples of financial capital include wealth, access to credit, and income from off-farm activities. Farm size, farm infrastructure, and access to transport are examples of physical capital. Under human capital, we list operator age, knowledge, skills and experience, family size and engagement, and access to labor. Social capital could include access to financial support, knowledge and technology, local markets, and labor through social networks. Capital assets affect an agent's ability to respond to certain stressors and harmful events, as well as to 
interact with institutions (Bebbington 1999). More importantly, social assets (human capital, social capital) can be just as valuable in defining adaptive capacity as financial and physical assets (Vasquez-Leon 2009; Smit and Wandel 2006).

We intend this paper be a first step towards building a more complete understanding of the interactions between multiscale biophysical, socio-economic, and institutional factors acting on southwestern cropland systems. In Section 2, we offer a short description of the region, including projected climate impacts. In Section 3, we offer case study "snapshots" of cropland systems in three counties in Arizona, New Mexico, and Utah to illustrate how different factors interact to determine contextual vulnerabilities in different locations.

\section{Study region}

Irrigated cropland agriculture in Arizona, New Mexico, and Utah provides the focus for this paper (Fig. 3). The combined land area of the three states is just over 0.5 million $\mathrm{km}^{2}$, with 0.26 million $\mathrm{km}^{2}$ or around $30 \%$ of the total area classified as desert. This is a region of low rainfall, yet irrigated cropland agriculture flourishes in locations with access to surface water or groundwater. Nearly all surface water used for irrigation originates as annual winter snowpack that accumulates in high elevation basins of the Southern Rocky Mountains. Two major snowfed rivers, the Colorado and the Rio Grande, together provide surface water for irrigating around $30,000 \mathrm{~km}^{2}$, as well as providing water to over 46 million people for municipal uses (International Boundary \& Water Commission 2017; USDI Bureau of Reclamation 2012). Where access to surface water is limited, there is greater reliance on groundwater for irrigation.

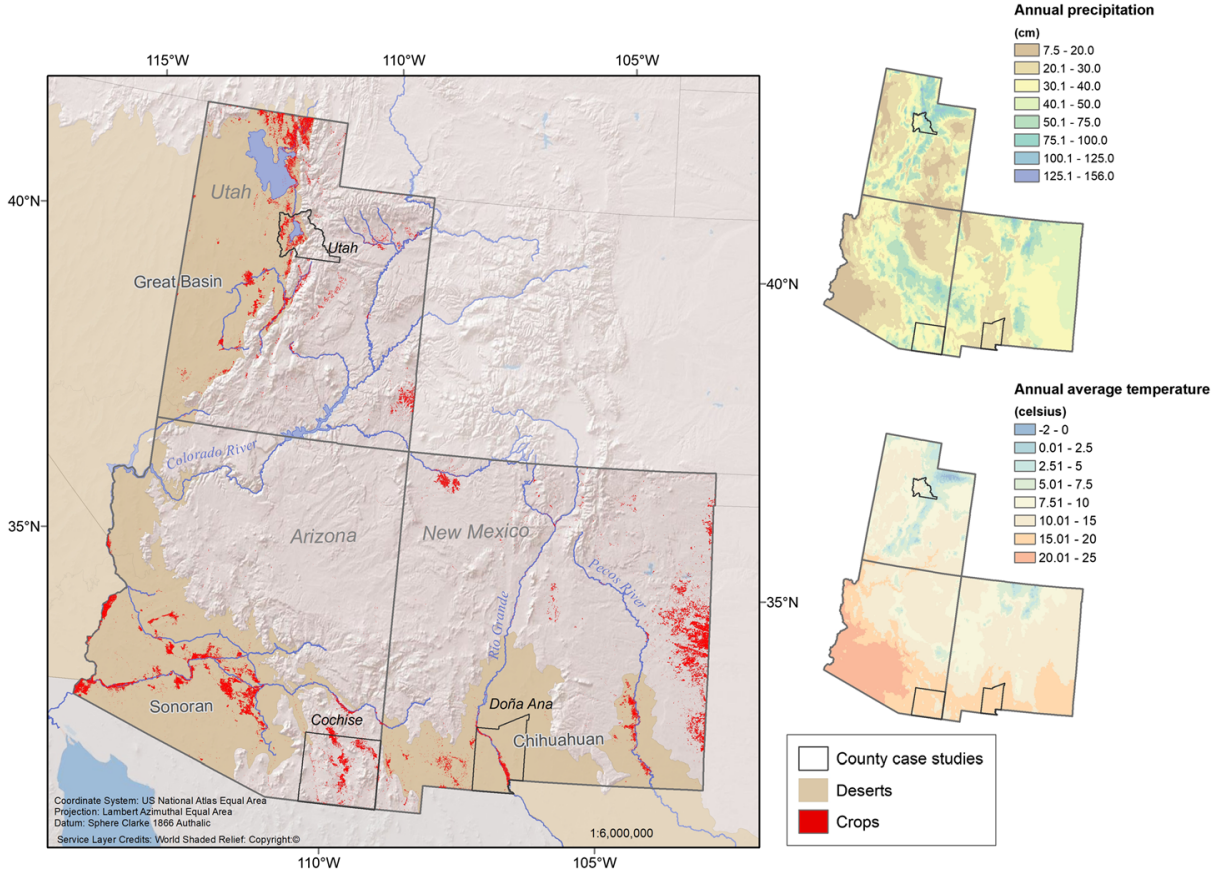

Fig. 3 Interior southwest dryland states, with 1981-2010 Climate Normals (Prism Climate Group 2016) 
In 2010, irrigation water withdrawals in the three dryland states accounted for between 72 and $85 \%$ of total water withdrawals (Maupin et al. 2014).

\subsection{Historical changes in climate and water resources}

Annual average temperatures in Arizona, New Mexico, and Utah range between 10 and $25^{\circ} \mathrm{C}$, and average summer temperatures can reach $35^{\circ} \mathrm{C}$ in southeastern Arizona and southern New Mexico and $32{ }^{\circ} \mathrm{C}$ in northern Utah (NOAA NCEI 2017). In cropland areas in southern New Mexico and Arizona, annual precipitation is usually less than $40 \mathrm{~cm}$. Eastern New Mexico and Utah croplands receive slightly more $(40-50 \mathrm{~cm})$.

The last six decades in the southwest were warmer than any other comparably long period in the last six centuries (Garfin et al. 2013). Temperatures during the early twenty-first century were consistently higher than for most of the twentieth century (MacDonald 2010) and heatwaves were more frequent in the 2000s than in any other decade since 1895 (Peterson et al. 2013). Precipitation trends over the last 35 years indicate that the southwest is already moving towards a drier state (Prein et al. 2016). There have been periods of significant drought during the 1930s (in the east of the region), the 1950s, and most recently in the 2000s. There is also evidence that the seasonality of the North American Monsoon (NAM), which in the south of the region delivers more than half the annual precipitation between July and September, is changing with delays in onset and closing, and with later occurrence in peak precipitation (Grantz et al. 2007).

Across the western U.S., the annual snowpack "reservoir" has been declining since the mid-twentieth century. Recent declines are driven by rising temperatures which reduce snow water equivalent, even when there are increases in precipitation (Mote et al. 2005). On average, 2000-2014 Colorado River annual flows were 19\% below the long-term 1906-1999 mean (Udall and Overpeck 2017). Although precipitation changes explain much of the interannual variability in streamflow, temperature is an important driving variable impacting Upper Colorado streamflow; temperature alone explained a mean streamflow departure of $-7 \%$ over the last 30 years (McCabe et al. 2017). Higher temperatures are also reducing runoff efficiencies in the Rio Grande with the data showing declining trends over the last 30 years (Lehner et al. 2017).

Groundwater reserves are also declining throughout the southwest. Since development, withdrawals of groundwater from almost all alluvial aquifers in the Southwest exceed recharge, with water declines of 15-60 m reported (Anderson 1995). And in some locations, water level declines have caused subsidence, leading to permanent loss of aquifer storage (Anderson 1995).

\subsection{Future changes in climate and water resources}

The southwest climate will continue its current drying and warming trend throughout the twenty-first century (Seager et al. 2010; Cook et al. 2015), and precipitation will decrease, driven in part by expansion of the sub-tropical dry zone (Dominguez et al. 2012). Average temperature projections suggest rises exceeding $1.7^{\circ} \mathrm{C}$ above recent historical averages (Cayan et al. 2013). Cropland agriculture will be exposed to warmer winters with fewer cold snaps and frost days, earlier spring onset, longer growing seasons, and summers with higher maximum daytime temperatures and warmer nighttime temperatures. Climate models project that extreme weather events (such as heatwaves, heavy rains, or hail) will also increase in frequency 
and magnitude (Gershunov et al. 2013). And drought, a long-term extreme event, will also become more frequent and more intense, likely exceeding the severity of medieval megadroughts (Cook et al. 2015). Increasing temperatures relative to declining precipitation will intensify negative trends in surface moisture balance (Jones and Gutzler 2016), thus reducing available moisture in the soil and exacerbating crop water stress. NAM seasonality is also projected to continue changing, with greater proportions of precipitation falling towards the end of the monsoon season (Cook and Seager 2013).

A warmer atmosphere will trigger cascading effects through the hydrological cycle reducing the water content of high elevation snowpack and decreasing aquifer recharge. Over the twenty-first century, temperature increases are likely to force even earlier springtime snowmelt than observed over the latter half of the twentieth century (Stewart et al. 2005). By mid-twentyfirst century, the Colorado River flow could see declines in streamflow exceeding $-10 \%$ relative to 1970-1999 flows (Vano et al. 2014). By 2100, northern Rio Grande flows could decline by $-25 \%$, Middle Rio Grande flows by 35\%, and below Elephant Butte Reservoir flows could decline as much as 50\% (Llewellyn and Vaddey 2013). Future groundwater supplies will be affected by climate change through impacts on aquifer recharge; southwestern aquifers could see future declines in total recharge between 10 and $20 \%$ depending on the primary recharge mechanism (Meixner et al. 2016).

\subsection{Urban expansion}

Urban expansion impacts agricultural land near the larger southwestern cities. In the three states combined, cropland area declined by 0.5 million ha between 1982 and 2012 (USDA NRCS 2016). In Utah, $79.5 \%$ of the population (2.43 million people) live in the five Wasatch Front counties (Cache, Weber, Davis, Salt Lake, and Utah) which between 2010 and 2016 collectively averaged a population growth rate over 10\% (USDA ERS 2017). These counties hold $21 \%$ of the State's harvested cropland (USDA NASS 2014). Maricopa and Pinal are two of the most populous counties in Arizona, containing 67\% of the population (4.67 million people) and with 2010-2016 population growth over 11\% (USDA ERS 2017). Maricopa and Pinal also contain about $47.6 \%$ of the state's harvested cropland (USDA NASS 2014). By comparison to Arizona and Utah, New Mexico experiences less population pressure and its population growth rate has fallen drastically over the last decade to $0.8 \%$ (previously $20.1 \%$ and $13.8 \%$ ) (USDA ERS 2017).

\section{Towards identifying contextual vulnerabilities in southwestern cropland agriculture}

In this section, we present "snapshot" example case studies of contextual vulnerabilities in three locations. Utah County (Utah) and Doña Ana (New Mexico) were selected, because both rank first in their states for crop sales (USDA NASS 2014). In these first two counties, we narrow down to the production of specific commodities that dominate county income (tart cherries and pecans) to demonstrate the role of institutional factors. Cochise County ranks sixth in Arizona for crop sales, but was selected as an example because it is one of the few locations in the Southwest where there has been research specifically on contextual vulnerability of agricultural communities that highlights the importance of capital assets and institutional factors (Vasquez-Leon et al. 2003; Vasquez-Leon 2009). These snapshots are not full 
vulnerability assessments and the examples given here comprise necessarily incomplete contextual analysis. We intend these examples to show that specific factors might feature prominently at one location or for a specific commodity, but may have less relevance at another location or for a different commodity.

\subsection{Utah County tart cherry production}

Utah State is the second largest producer of tart cherries (Prunus cerasus) in the USA, albeit a distant second behind Michigan (USDA NASS 2014) and Utah County leads the state in tart cherry production. Growing tart cherries can be a risky enterprise, because cherry trees are sensitive to multiple environmental stresses, and cherry orchards require a long investment period (at least 6 years after planting) before farmers see a return from their crop (Thornsbury and Martinez 2012). From the core system perspective (Fig. 2), climate change exposes cherry trees to higher temperatures in summer, later onset of cold temperatures in fall, reduced chilling hours in winter, and earlier spring onset. These factors reduce yield, impair fruit quality, and, in the worst-case scenario, cause crop failure from freeze-induced blossom damage. Earlier spring onset is the most a critical factor exposing growers to losses because it increases risk of bud exposure to a late hard frost or freeze event (Winkler et al. 2013). Frost and freeze events were the primary causes of loss to Utah County's tart cherry crop between 2001 and 2016 (USDA RMA 2017). There are management interventions that can help cherry growers respond to adverse climate events, but these represent higher input costs, adding another source of economic stress on cherry growers besides the long investment period. Thus, the ability of growers to cope with climate events will depend upon their access to capital assets.

Also represented in the core part of Fig. 2, population growth and rapid urbanization in Utah County contribute to the potential impacts from climate change. Between 2010 and 2016, Utah County population grew by $13.8 \%$ to almost 600,000 , primarily through natural increase (USDA ERS 2017), and population is likely to more than double by mid-century (Envision Utah 2016). Estimates of land use change suggest that half the remaining farmland in Utah County (almost 26,000 ha) will be developed by 2050 (Envision Utah 2016).

One adaptation option in response to climate change would be for farmers to move out of tart cherry farming and into other crops. Responding to urbanization, another more drastic option would be to sell land to developers (where permitted). However, there is insufficient evidence in agricultural census data to show that famers are moving out of tart cherries either to other crops or through land sales, despite warming temperatures through the 2000s and increasing pressure from urban expansion. On the contrary, tart cherry orchard area has steadily increased since 2002, with non-bearing area (presumably newly planted orchards) doubling between 2007 and 2012 (USDA NASS 2014). This would suggest that despite the risks of failed harvests, there are good reasons for farmers to invest more land area and more capital in tart cherries.

With reference to the core part of Fig. 2, the discussion of tart cherries so far would suggest that tart cherry producers are very exposed to climate and development-related stressors that could result in crop failure. However, crop failure does not necessarily translate into deleterious impacts on farmers' income or livelihoods. In terms of the institutional context, farm scale biophysical and economic pressures exist alongside national policies and market forces and it is these factors that reduce vulnerability for tart cherry producers in Utah County. For example, low tart cherry yields, low prices, low quality, or any combination of events can be protected through insurance policies subsidized by the USDA RMA (USDA RMA 2017). 
Vulnerability is also affected by markets, including the price received for a given commodity because these factors tie into farm income and livelihood security. In this respect, the importance of the institutional context is exemplified by the disastrous national tart cherry harvest in 2002. Domestic tart cherry production varies widely from year to year because around $75 \%$ of the nation's tart cherry crop is concentrated in Michigan where a single weather event such as a late spring freeze can have a disproportionately large impact on aggregate supplies (White and Kesecker 2007). In 2002, Michigan lost 95\% of their crop to a late freeze, and at the same time, Utah lost $75 \%$ of their crop through frost (USDA NASS 2002). After the massive 2002 crop failures, domestic customers turned to imported cherries. Before this time, US cherry markets had been isolated from foreign markets, but since 2002, imports have remained high (Thornsbury and Martinez 2012). However, strong national institutional support maintains stable markets for cherry growers, reducing their vulnerability to climate shocks, either locally in Utah County or over 1500 miles away in Michigan. One of the ways in which the tart cherry industry protects prices received by farmers is through a Federal Marketing Order administered by the Cherry Industry Administrative Board (CIAB). The CIAB's main purpose is to balance supply and demand, but they also run promotional campaigns to expand demand for tart cherries (Milkovich 2015). Two other "pillars" supporting the tart cherry industry are the super-cooperative CherrCo which stabilizes prices for frozen cherries and the Cherry Marketing Institute, which works to expand new markets (Milkovich 2015).

\subsection{Doña Ana County pecan nut production}

Doña Ana County in southern New Mexico is bisected by a thin ribbon of cropland that follows the north-south course of the Rio Grande valley below Elephant Butte Reservoir. Pecan (Carya illinoinensis) is the primary income-producing crop in Doña Ana and the crop covering the largest area $(\sim 12,000 \mathrm{ha})$, ahead of alfalfa (8000 ha) and other common southwestern field crops. Agricultural censuses show pecan orchard area steadily increasing since 2002. (USDA NASS 2014), likely driven by demand from China, especially since 2007 (Grauke et al. 2016). Although Doña Ana faces similar issues to Utah County with respect to loss of agricultural land to development, it is at a much smaller scale. Doña Ana population grew by 2.4\% between 2010 and 2016, to just over 210,000 (USDA ERS 2017).

With respect to the core part of Fig. 2, some of the critical climate-related events that impair pecan production in New Mexico include late spring and early autumn freezes and drought (Grauke et al. 2016). And according to the RMA, main causes of loss for Doña Ana pecan nuts between 2001 and 2016 were excessive windiness and hail (USDA RMA 2017). This RMA report is interesting because irrigation supply failure (insufficient water affected production) was the main climate-related cause of loss for all insured crops in Doña Ana between 2001 and 2016. The reason why pecan nut production was less impacted by irrigation supply failure is not clear but RMA findings may imply that pecan nut producers with crop insurance have good access to groundwater. The annual water needs for pecan trees in this region are 15,000 to 18,000 cubic meters per hectare, of which under half is supplied by surface water (Wells 2014). In any event, irrigation supply failure as a cause of loss may become more significant to pecan growers in the future. With hotter temperatures, increasing evaporative demand, and a longer growing season, pecan orchards will require increased irrigation to prevent production losses or damage to crop quality. In times of drought, farmers may rely entirely on groundwater pumping, even though this raises the costs of production and exposes crops to greater levels of salinity (Ward 2014). The estimated 50\% mid-century decline in Rio Grande flows 
below Elephant Butte Reservoir flows (Llewellyn and Vaddey 2013) will impact pecan growers, driving greater dependence on the more expensive groundwater supplies. Water shortages will also be exacerbated by increasing demands from the region's growing urban population and by increasing groundwater salinity (Hargrove et al. 2013).

Here, the institutional context of water rights adds complexity to future water supply scenarios and demonstrates the need to understand institutional drivers and biophysical drivers of vulnerability. Doña Ana shares borders and Rio Grande water with Mexico and Texas, and it is a region of highly contentious water issues. In 2013, in the latest of a series of legal wrangles, Texas submitted a complaint before the US Supreme Court claiming that New Mexico is using water in excess of its apportionment under the 1938 Rio Grande Compact (Wheat 2015). If the Supreme Court rules in favor of Texas, it is possible that limitations on groundwater pumping in Doña Ana may be imposed (Wheat 2015), thus affecting one of the means by which Doña Ana pecan growers supplement their surface water.

Under climate change and possible reduced allocations of water, an aspect of New Mexico Water Law may result in differential impacts on Doña Ana surface water users and is an example of local institutional context. New Mexico uses the legal doctrine of prior appropriation, or "first in time, first in right" for water allocation. In times of shortage, senior water rights holders receive their water from the available water supply before junior water rights holders. The New Mexico Office of the State Engineer (OSE) launched the Active Water Resource Management initiative to build the infrastructure to conduct priority administration (New Mexico Office of the State Engineer 2004). In future, junior water rights holders could be more vulnerable to water scarcity than senior water rights holders, although the OSE stresses that a "priority call" should be a measure of last resort.

Recent events have uncovered another source of contextual vulnerability for Doña Ana pecan growers. In Fig. 2, we distinguished between sub-national markets (local to regional institutions) and international markets because in the production of any commodity, there will be producers selling their products locally, regionally, or internationally. In the case of pecan farmers in Doña Ana, farmers have the option to sell their pecans to commercial buyers, who then sell on to international markets. In March 2018, China, the largest importer of pecans from the USA imposed higher tariffs on multiple US products in response to new US tariffs on Chinese aluminum and steel. US pecan nuts are now subject to a $22 \%$ tariff, up from $7 \%$. This gives Mexican, South African, and Australian pecan nuts a competitive advantage in Chinese markets and may ultimately have impacts on farmers' profits in the USA (Pecan Report 2018).

\subsection{Cochise County cropland agriculture}

Most croplands in Cochise County in southeastern Arizona are located in the Sulphur Springs Valley in the Willcox Basin. In 2012, major crops included corn, alfalfa, cotton, and pecans (USDA NASS 2014). Referring to the core part of Fig. 2, access to water is one of the most important biophysical variables affecting climate change vulnerability in Cochise. With no surface water, groundwater is the main source for irrigation in the Sulphur Springs Valley and it is depleting. Willcox Basin recharge estimates range from 18.5 to 58 million cubic meters per year, while groundwater discharge from groundwater pumping is estimated at 217 million cubic meters per year (Arizona Department of Water Resources 2014). Depth-to-water (DTW) increased in 549 wells in the Willcox Basin between 1999 and 2005; wells with the most severe DTW increases are located in the primary agricultural area of Sulphur Springs Valley (Jacobson et al. 2008). Even though groundwater is declining, the leading causes of loss of insured crops between 2001 and 
2016 were freeze events, followed by excess moisture and hail; failure of irrigation supply was the fourth most widespread cause of loss, impacting 1703 ha between 2001 and 2016. (USDA RMA 2017). Urban expansion is not a significant problem in Cochise. On the contrary, population decreased between 2010 and 2016 by $-4.3 \%$ to just over 125,000 people (USDA ERS 2017). However, one source of concern reported in the media is the expansion of pistachio and pecan nut farms in Cochise reportedly driven by farmers moving from southern California to Arizona, ironically in search of more reliable water supplies (Blake 2017).

Unlike Utah County and Doña Ana, information on farmers' demographics and their contextual vulnerabilities exists for Cochise County through research by Vasquez-Leon et al. (2003) and Vasquez-Leon (2009). Vasquez-Leon's research offers unique insights into how sociocultural and institutional factors influence risk in different ethnic groups, and her insights are likely applicable in other locations in the southwest. While access to groundwater plays a role in vulnerability to climate change, access to technology and financial resources affect the level of harm that different groups experience through adverse weather and climate events (sensitivity) and how they can respond to these events (adaptive capacity). For example, Anglo farmers invest more in new technology (e.g., center-pivot technology) and crop diversification than Hispanic farmers (Vasquez-Leon et al. 2003), and they own larger farms with land in different areas, thus making their operations less sensitive to the localized weather events that are common in this region (Vasquez-Leon 2009). By comparison, Hispanic farmers own or rent smaller land parcels (affecting eligibility for loans), are less likely to invest in technology, and are also less likely to grow commodity crops that are subsidized under USDA programs (Vasquez-Leon 2009). However, profits from commodity crops are affected by trade policies such as the North American Free Trade Agreement (Coles and Scott 2009). By growing high value vegetable crops for local and regional Mexican and Mexican-American markets, Hispanic farmers can avoid exposure to North American market fluctuations. Overall, Anglo farmers and Hispanic farmers depend on different support networks, which will affect their vulnerability in different ways. Where Anglo farmers may utilize institutional support for loans, market access, or labor recruitment, Hispanic farmers rely on strong social ties (Vasquez-Leon 2009). Through informal social capital, Hispanic farmers have access to loans (from friends and family), markets (via like-minded growers and agents), and farmworkers. In short, they can access economic or human capital with less financial cost than if they were engaged in formal institutional networks.

\section{Conclusion}

In this paper, we reviewed potential impacts of climate change on cropland systems in the arid interior southwest U.S. We presented a diagram to illustrate how contextual and biophysical factors interact to influence vulnerability and we used examples from three southwestern counties to demonstrate how the prominence of different factors varies with location and commodity. We recognized that traditional biophysical vulnerability assessments are valuable because they provide data on potential impacts on cropland systems and can help inform technical adaptive solutions. We also discussed why it is important to consider contextual vulnerabilities in cropland systems. Adaptation in cropland systems is a farm-based activity. Indeed, farmers already rely on technical solutions to cope with or react to climate variability and water scarcity on a year-to-year basis. Future deviation from current climate norms may stretch these coping strategies to their limits, incurring costs and other stresses within the system that push southwestern cropland operations beyond the range of coping, to 
transformation, or even cessation of farm operations. The southwest presents diverse challenges to cropland agriculture; some areas will be more affected by groundwater depletion, others by declining surface water supplies; in some areas, urban expansion is competing with agriculture for land and water; specialty crop farmers with perennial crops face long investment periods and exposure to wider price and market uncertainties; some farmers depend on institutional support, others rely more on friends and colleagues; some commodities are exposed to global markets, others find stability in a more local market; landowners with large farms have greater financial and infrastructural security than tenant-farmers with some parcels of land; government policies may inadvertently favor one group of farmers over another. There are many ways in which non-climate factors interact with potential climate impacts. Understanding contextual vulnerabilities will allow us to determine what kind of practical financial, institutional, and policy-level resources will be necessary to help farmers adjust to new conditions and to allow productive cropland agriculture to continue in the southwest.

Open Access This article is distributed under the terms of the Creative Commons Attribution 4.0 International License (http://creativecommons.org/licenses/by/4.0/), which permits unrestricted use, distribution, and reproduction in any medium, provided you give appropriate credit to the original author(s) and the source, provide a link to the Creative Commons license, and indicate if changes were made.

\section{References}

Adger W (2003) Social capital, collective action, and adaptation to climate change. Econ Geogr 79(4):387-404 Anderson TW (1995) Summary of the southwest alluvial basins, regional aquifer-system analysis, South-Central Arizona and parts of adjacent states. U.S. Geological Survey, Washington, DC

Arizona Department of Water Resources (2014) Hydrology of the Willcox Basin. Arizona Department of Water Resources, Phoenix, AZ. Available: http://www.azwater. gov/AzDWR/StatewidePlanning/WaterAtlas/SEArizona/Hydrology/Willcox.htm. Accessed 23/09 $/ 2017$

Bebbington A (1999) Capitals and capabilities: a framework for analyzing peasant viability, rural livelihoods and poverty. World Dev 27(12):2021-2044

Blake C (2017) Arizona tree nut plantings on the fast track, Western Farm Press. Available: http://www. westernfarmpress.com/tree-nuts/arizona-tree-nut-plantings-fast-track. Accessed 20/04/2017

Cayan, D.M., Tyree, M., Kunkel, K.E., Castro, C., Gershunov, A., Barsugli, J., Ray, A.J., Overpeck, J., Anderson, M., Russell, J., Rajagopalan, B., Rangwala, I., Duffy, P., 2013. Future climate: projected averages. In: G. Garfin, A. Jardine, R. Merideth, M. Black, S. LeRoy (Eds.), Assessment of climate change in the Southwest United States: a report prepared for the National Climate Assessment. Island Press, Washington, DC, pp. 101-125

Coles A, Scott C (2009) Vulnerability and adaptation to climate change and variability in semi-arid rural southeastern Arizona, USA. Nat Res Forum 33(4):297-309

Cook B, Seager R (2013) The response of the North American Monsoon to increased greenhouse gas forcing. J Geophys Res Atmos 118(4):1690-1699

Cook BI, Ault TR, Smerdon JE (2015) Unprecedented 21st century drought risk in the American Southwest and Central Plains. Sci Adv 1(1):e1400082

Dominguez F, Rivera E, Lettenmaier D, Castro C (2012) Changes in winter precipitation extremes for the western United States under a warmer climate as simulated by regional climate models. Geophys Res Lett 39:L05803

Envision Utah (2016) Utah County Agriculture Toolbox. Available: http://www.utahagriculture.org/ Accessed 20 $/ 04 / 2018$

Garfin G, Jardine A, Merideth R, Black M, LeRoy S (2013) Assessment of climate change in southwest United States: a report prepared for the National Climate Assessment. Island Press, Washington DC

Gershunov A, Rajagopalan B, Overpeck J, Guirguis K, Cayan D, Hughes M, Dettinger M, Castro C, Schwartz RE, Anderson M, Ray AJ, Barsugli J, Cavazos Y, Alexander M (2013) Future climate: projected extremes. In: Garfin G, Jardine A, Merideth R, Black M, LeRoy S (eds) Assessment of climate change in the 
Southwest United States: a report prepared for the National Climate Assessment. Island Press, Washington, DC, pp 126-147

Grantz K, Rajagopalan B, Clark M, Zagona E (2007) Seasonal shifts in the North American monsoon. J Clim 20(9):1923-1935

Grauke LJ, Wood BW, Harris MK (2016) Crop vulnerability: Carya. Hortscience 51(6):653-663

Hargrove W, Borrok D, Heyman J, Tweedie C, Ferregut C (2013) Water, climate, and social change in a fragile landscape. Ecosphere 4(2):1-13

Iglesias A, Minguez M (1997) Modelling crop-climate interactions in Spain: vulnerability and adaptation of different agricultural systems to climate change. Mitig Adapt Strateg Glob Chang 1(3):273-288

International Boundary \& Water Commission (2017) About the Rio Grande. International Boundary and Water Commission, US Section, El Paso, TX. Available: http://www.rgisc.org/about-the-rio-grande.html. Accessed $23 / 09 / 2017$

Jacobson J, Davis T, Hinckley A, Schmerge D, Flora S (2008) Water level changes in the Willcox Basin, Arizona 1999-2005. Arizona Department of Water Resources, Phoenix

Jones S, Gutzler D (2016) Spatial and seasonal variations in aridification across Southwest North America. J Clim 29(12):4637-4649

Kelly P, Adger W (2000) Theory and practice in assessing vulnerability to climate change and facilitating adaptation. Clim Chang 47(4):325-352

Lehner F, Wahl ER, Wood AW, Blatchford DB, Llewellyn D, Conde C, Liverman D, Flores M, Ferrer R, Araújo R, Betancourt E, Villarreal G, Gay C (2017) Assessing recent declines in Upper Rio Grande runoff efficiency from a paleoclimate perspective. Geophys Res Lett 44(9):4124-4133

Liverman DM, Merideth R (2002) Climate and society in the US Southwest: the context for a regional assessment. Clim Res 21(3):199-218

Llewellyn D, Vaddey S (2013) West-wide climate risk assessment: Upper Rio Grande impact assessment. USDI Bureau of Reclamation, Albuquerque

MacDonald GM (2010) Water, climate change, and sustainability in the southwest. Proc Natl Acad Sci 107(50): 21256-21262

Marshall N, Stokes C, Webb N, Marshall P, Lankester A (2014) Social vulnerability to climate change in primary producers: a typology approach. Agric Ecosyst Environ 186:86-93

Maupin MA, Kenny JF, Hutsone SS, Lovelace JK, Barbar NL, Linsey KS (2014) Estimated use of water in the United States in 2010. Circular 1405. US Geological Survey, Reston

McCabe GJ, Wolock DM, Pederson GT, Woodhouse CA, McAfee S (2017) Evidence that recent warming is reducing Upper Colorado River flows. Earth Interact 21(10):1-14

McCarthy J, Canziani O, Leary A, Dokken D, White K (2001) Climate change 2001: impacts, adaptation, and vulnerability, intergovernmental panel on climate change, Cambridge, UK and New York, USA

Meixner T, Manning A, Stonestrom D, Allen D, Ajami H, Blasch K, Brookfield A, Castro C, Clark J, Gochis D, Flints A, Neff K, Niraula R, Rodell M, Scanlon B, Singha K, Walvoord M (2016) Implications of projected climate change for groundwater recharge in the western United States. J Hydrol 534:124-138

Milkovich M (2015) 'Three pillars' uphold the tart cherry industry, Fruit Growers News. Fruitgrowersnews.com. Great American Media Services \& Fruit Growers News, Sparta, MI. Available: http://fruitgrowersnews. com/news/three-pillars-uphold-the-tart-cherry-industry/. Accessed 23/09/2-17

Mote PW, Hamlet AF, Clark MP, Lettenmaier DP (2005) Declining mountain snowpack in western North America. Bull Am Meteorol Soc 86(1):39-49

New Mexico Office of the State Engineer (2004) Active water resource management. New Mexico Office of the State Engineer Interstate Stream Commission, Santa Fe, NM. Available: http://www.ose.state.nm. us/AWRM/index.php. Accessed 23/09/2017

NOAA NCEI (National Centers for Environmental information) (2017) Climate at a glance: U.S. Time Series, Maximum Temperature. Available: https://www.ncdc.noaa.gov/cag/. Accessed 23/09/2017

O'Brien K, Eriksen S, Nygaard L, Schjolden A (2007) Why different interpretations of vulnerability matter in climate change discourses. Clim Pol 7(1):73-88

Pecan Report (2018) Pecan tariffs and the China U.S. trade war. Available: http://www.pecanreport.com/newsblog/2018/4/3/pecan-tariffs-and-the-china-us-trade-war. Accessed 22 April 2018

Peterson T, Heim R, Hirsch R, Kaiser D, Brooks H, Diffenbaugh N, Dole R, Giovannettone J, Guirguis K, Karl T, Katz R, Kunkel K, Lettenmaier D, McCabe G, Paciorek C, Ryberg K, Schubert S, Silva V, Stewart B, Vecchia A, Villarini G, Vose R, Walsh J, Wehner M, Wolock D, Wolter K, Woodhouse C, Wuebbles D (2013) Monitoring and understanding changes in heat waves, cold waves, floods and droughts in the United States: state of knowledge. Bull Am Meteorol Soc 94(6):821-834

Prein A, Holland G, Rasmussen R, Clark M, Tye M (2016) Running dry: the US Southwest's drift into a drier climate state. Geophys Res Lett 43(3):1272-1279 
Prism Climate Group (2016) 30-Year Normals (1981-2010). Available: http://www.prism.oregonstate. edu/normals/. Accessed 23/09/2017

Seager R, Naik N, Vecchi GA (2010) Thermodynamic and dynamic mechanisms for large-scale changes in the hydrological cycle in response to global warming*. J Clim 23(17):4651-4668

Smit B, Wandel J (2006) Adaptation, adaptive capacity and vulnerability. Glob Environ Chang 16(3):282-292

Stewart I, Cayan D, Dettinger M (2005) Changes toward earlier streamflow timing across western North America. J Clim 18(8):1136-1155

Thornsbury S, Martinez L (2012) Capturing demand for functional foods: a case study from the tart cherry industry. Am J Agric Econ 94(2):583-590

Turner BL, Kasperson RE, Matson PA, McCarthy JJ, Corell RW, Christensen L, Eckley N, Kasperson JX, Luers A, Martello ML, Polsky C (2003) A framework for vulnerability analysis in sustainability science. Proc Natl Acad Sci 100(14):8074-8079

Udall B, Overpeck J (2017) The twenty-first century Colorado River hot drought and implications for the future. Water Resour Res 53(3):2404-2418

USDA ERS (Economic Research Service) (2017) Population. U.S. Department of Agriculture, Washington, DC. Available: https://data.ers.usda.gov/reports.aspx?ID=17827. Accessed 23/09/2017

USDA NASS (National Agricultural Statistics Service) (2002) Cherry production, U.S. Department of Agriculture, Washington, DC. Available: http://usda.mannlib.cornell.edu/usda/nass/CherProd//2000s/2002 /CherProd-07-01-2002.pdf. Accessed 23/09/2017

USDA NASS (National Agricultural Statistics Service) (2014) Census of agriculture 2012, U.S. Department of Agriculture, Washington, DC

USDA NRCS (Natural Resources Conservation Service) (2016) Soil and Water Resources Conservation Act/ Natural Resource Inventory Cropland. Available: https://www.nrcs.usda. gov/wps/portal/nrcs/rca/national/technical/nra/rca/text/\#NRI\%20Cropland Accessed 23/09/2017

USDA RMA (Risk Management Agency) (2017) Cause of Loss Historical Data Files. U.S. Department of Agriculture, Washington, DC. Available: https://www.rma.usda.gov/data/cause.html. Accessed 22/04/2018

USDI Bureau of Reclamation (2012) Reclamation: managing water in the West, U.S. Department of Interior, Washington, DC

Vano JA, Udall B, Cayan DR, Overpeck JT, Brekke LD, Das T, Hartmann HC, Hidalgo HG, Hoerling M, McCabe GJ (2014) Understanding uncertainties in future Colorado River streamflow. Bull Am Meteorol Soc 95(1):59-78

Vasquez-Leon M (2009) Hispanic farmers and farmworkers: social networks, institutional exclusion, and climate vulnerability in Southeastern Arizona. Am Anthropol 111(3):289-301

Vasquez-Leon M, West C, Finan T (2003) A comparative assessment of climate vulnerability: agriculture and ranching on both sides of the US-Mexico border. Glob Environ Chang 13(3):159-173

Ward F (2014) Economic impacts on irrigated agriculture of water conservation programs in drought. J Hydrol 508:114-127

Wells L (2014) Cost of pecan production, exhibit 68, public hearing for proposed marketing order and agreement for pecans, USDA agricultural marketing service. Available: https://www.ams.usda. gov/sites/default/files/media/exhibit\%2068.pdf. Acessed 22 April 2018

Wheat E (2015) Groundwater challenges of the lower Rio Grande: a case study of legal issues in Texas and New Mexico. Resources 4(2):13

White GB, Kesecker K (2007) Economic analysis of the tart cherry federal marketing orders, Cherry Industry Administrative Board, DeWitt, MI. Available: http://www.cherryboard. org/TartCherryExecSummaryFINAL.pdf. Accessed 23/09/2017

Wilhelmi OV, Wilhite DA (2002) Assessing vulnerability to agricultural drought: a Nebraska case study. Nat Hazards 25(1):37-58

Winkler JA, Andressenm JA, Bisanz JM, Guentchev G, Nugent J, Piromsopa K, Rothwell N, Zavalloni C, Clark J, Min HK, Pollyea A, Prawiranata H (2013) Michigan's tart cherry industry: vulnerability to climate variability and change. In: Pryor SC (ed) Climate change in the Midwest. Indiana University Press, Bloomington, pp 104-115 